Research Article | Internal Medicine

\title{
Level of Knowledge and Awareness of Diabetic Emergencies Among Turkish Bus Drivers: Example of the Mediterranean Region
}

\author{
Sibel Şentürk ${ }^{1 *}(\mathbb{D})$, Nurten Terkeş $^{1}$ (D)
}

\begin{abstract}
The objective of this research was to determine the level of knowledge and awareness of diabetic emergencies among Turkish bus drivers.

Methods. The universe of this descriptive and cross-sectional study was all the individuals working as bus drivers in the Mediterranean Region between January-June 2019, and the study sample was 1292 drivers who met the inclusion criteria of the research. Data were collected by the Personal Information Form and the Diabetic Emergency Information and Awareness Survey Form. Descriptive statistics, the Mann-Whitney U test and the Kruskal-Wallis test were used in data evaluation.

Results. The average age of bus drivers participating in the study was $38.29 \pm 9.44$ years, while their average work experience was $12.50 \pm 8.92$ years. Among them, $14.9 \%$ of bus drivers had a diabetic family member; $23.7 \%$ of bus drivers had a first aid certificate; $11.5 \%$ of bus drivers received diabetes-related training. The average score of drivers for the level of knowledge and awareness regarding diabetic emergencies was found to be $15.39 \pm 4.72$. There was a statistically significant difference between the drivers' average scores for the level of knowledge and awareness and their age, education status, work experience, the presence of chronic disease, the presence of a diabetic family member, the presence of a first aid certificate, diabetes-related training, the place of receiving this training variables $(p<0.05)$.

Conclusions. Bus drivers were found to have above average levels of knowledge and awareness of diabetic emergencies. Bus drivers are recommended to be trained on diabetic emergencies and raising awareness of diabetes mellitus to ensure a proper intervention in case of emergencies in individuals with diabetes mellitus during travels.
\end{abstract}

\section{Keywords}

Bus Driver; Diabetic Emergencies; Knowledge Level; Awareness

${ }^{1}$ Department of Nursing, Bucak Health School, Burdur Mehmet Akif Ersoy University, Bucak-Burdur, Turkey

*Corresponding author: sibelsenturk@mehmetakif.edu.tr

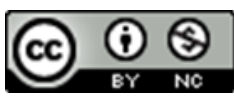

Copyright @Sibel Şentürk, Nurten Terkeş, 2021

\section{Introduction}

Diabetes mellitus (DM) is a global public health challenge since it is one of the most rapidly growing health concerns throughout the world; its incidence has increased among all age groups; it causes acute and chronic complications and results in irreversible organ disorders, being one of the top five reasons of death; the treatment requires the high cost [1,2]. According to the International Diabetes Federation (IDF) Diabetes Atlas (2019), it is estimated that there are 463 million people with DM at the age of 20-79 years worldwide, and there will be 578 million in 2030, and 700 million in 2045 [3].
In Turkey, the prevalence of DM in the 20-79 age group, according to the Turkish Diabetes Epidemiology Study (TURDEP I) and TURDEP II, was reported to be $7.2 \%$ and $13.7 \%$, respectively $[4,5]$. According to IDF data, the prevalence of DM in Turkey is $12.8 \%$ and there are 6.7 million people living with this disease [3].

DM is stated as the second most common chronic disease which is seen in individuals who travel and is accepted as a challenging situation for individuals who have difficulty in following their home-routines in places where they travel $[6,7]$. As the incidence of DM and the number of peo- 
ple who travel increase day by day, the number of passengers with DM is also increasing $[8,9]$. In the literature, it is stated that individuals with DM experience metabolic emergencies such as hypoglycemia, hyperglycemia, and diabetic ketoacidosis due to conditions such as skipping or forgetting insulin administration hours during their travels, inadequate intake of nutrients and fluids after insulin administration, not adapting to their diet, and excessive fatigue [6-8, 10-15]. Success in emergency interventions depends primarily on the presence of a well-trained and sufficient workforce in this regard [16]. The lack of awareness and information on DM in society prevents early diagnosis. Therefore, it is very important to raise awareness for DM in society; to delay its occurrence by controlling the blood glucose level at an early level; to reduce metabolic complications in people with DM through timely and informed interventions; to prevent diabetic complications such as neuropathy, retinopathy, nephropathy, cardiovascular diseases; to increase quality of life in individuals and prolong their life [17].

Bus driver activities are among professions with a strong impact on public safety. Passenger transport is closely related to the responsibility for other people's lives [18]. Today, due to the increase in the number of patients with DM, it is necessary to ensure the participation of bus drivers, who are constantly in contact with people in public places and who will perform the first intervention during travel of individuals with $\mathrm{DM}$, in the training programs related to diabetic emergencies periodically.

From this point of view, the objective of this research was to determine the level of knowledge and awareness of diabetic emergencies among Turkish bus drivers.

\section{Materials and Methods}

\section{Study Design}

This study was conducted in a descriptive and cross-sectional manner.

\section{Setting and Sample}

The universe of the study was all bus drivers in 7 provinces in the Mediterranean Region between January - June 2019. Sample size in the study was calculated by using

$$
n=N t^{2} p q / d^{2}(N-1)+p q
$$

formula, where $\mathrm{N}$ stands for the number of people in the universe; $t$ stands for the accepted significance level, type 1 (alpha) error level $=5 \%$ corresponding value: 1.96 ; $\mathrm{p}$ stands for the frequency of the condition we are investigating $(10 \%=0.10)$ $\mathrm{q}$ stands for the frequency of absence of the condition we are examining $(90 \%=0.90)$; d stands for sampling error accepted by the researcher $(1 \%=0.01)$ [19]. The number of bus drivers in each city was 5205 (Osmaniye - 116; Isparta - 200; Antalya - 3708; Kahramanmaraş - 300; Mersin - 421; Burdur 110; Hatay - 350); the confidence interval was taken as $95 \%$; the error rate was taken as $5 \%$; the sample size in each city was calculated; the minimum sample size was found as 1208 . The study was completed with 1292 individuals (Osmaniye - 90; Isparta - 140; Antalya - 398; Kahramanmaraş - 172; Mersin - 205; Burdur - 97; Hatay - 190) at the age of $\geq 18$ years, who did not have sensory vision and hearing loss, were open to verbal communication, filled out the questionnaire between the dates when the survey was conducted and agreed to participate in the study.

\section{Instruments}

Data were collected by a survey form [17, 18, 20-24] created by researchers by scanning the literature. The survey form consisted of two parts and a total of 41 questions. The first part of the survey form had 17 questions about bus drivers' age, gender, education level, marital status, income status, weekly working hours, work experience, the presence of chronic disease, the presence of a family member with DM, the degree of closeness with the family member with DM, the presence or absence of a first aid certificate, the status of information about which numbers to call in case of emergency, whether they had DM-related training, the place of this training, whether they have ever encountered a passenger with DM before; the second part had 24 questions regarding bus drivers' information levels and awareness of diabetic emergencies. The pre-study survey form was reviewed for integrity by taking the opinion of a professor specializing in diabetes nursing, and some statements were corrected. Pre-application with 5 individuals was conducted and the study took its final version.

\section{Data Collection}

Data were filled by the researchers using face-to-face interview methods in the waiting room before the departing hours in 7 provinces of the Mediterranean Region between January and June 2019. Before the application, the objective and method of the research were explained to the bus drivers who participated in the research. The survey took approximately 10-15 min.

\section{Data Analysis}

SPSS 21.0 (Statistical Package for the Social Sciences, Chicago, Illinois) package program was used in data evaluation. Sociodemographic characteristics and the level of knowledge and awareness of diabetic emergencies were given as the number, percentage, mean and standard deviation. The ShapiroWilk test was used to assess the normality of data distribution. The Mann-Whitney U test was used in the comparison of paired groups in level of knowledge and awareness of diabetic emergencies with sociodemographic characteristics; the Kruskal-Wallis test was used in the comparison of three or more groups. The statistical significance level was accepted as $\mathrm{p}<0.05$.

\section{Limitations}

This study has some limitations. First, there are 8 provinces in the Mediterranean region; however, the study was completed in the 7 provinces as permission to conduct the study could 
not have been obtained in Adana province. Secondly, this study does not generally reflect bus drivers in Turkey and is limited to bus drivers in the Mediterranean Region who agreed to participate in the study.

\section{Results}

The mean age of bus drivers included in the study was $38.29 \pm 9.44$ years; all the participants were males; $62.3 \%$ of the participants had a high school education level and above; $85.8 \%$ of the participants were married; $10.4 \%$ of the participants had a chronic disease; $14.9 \%$ of bus drivers had a family member with DM; $23.7 \%$ of the participants had a first aid certificate; $95.1 \%$ of the participants knew the numbers to call in case of emergency; $11.5 \%$ of the participants received DM-related training. Sociodemographic characteristics of bus drivers are given in Table 1.

Table 2 shows the responses of bus drivers who participated in the study to the 24-item "Information on Diabetic Emergencies and Awareness Survey." The average score of bus drivers for the level of knowledge and awareness regarding diabetic emergencies was found to be $15.39 \pm 4.72$. The most "yes" answers were given to the following items: $93.8 \%$ of bus drivers stated that "I can get the passenger off of the bus, and lie them down on a flat, hard floor on their backs"; $93.7 \%$ of bus drivers stated that "I know what DM is"; $93.6 \%$ of bus drivers stated that "If there is a crowd around the passenger, I can disperse it and calm down the passenger"; $91.7 \%$ of bus drivers stated that "I will call 112 if symptoms do not go away after the intervention for the passenger with low blood sugar"; $91.4 \%$ of bus drivers stated that "I will try to receive information if the passenger has a relative", and "I can measure passenger's blood sugar if they have a blood glucose meter in their bags." Bus drivers were found to give the least "yes" answers to the following questions: $14.9 \%$ of them stated that "I have an idea about what gestational diabetes is"; $24.5 \%$ of bus drivers stated that "If the passenger with low blood-sugar is unconscious and has a glucagon injector in the bag, I can apply it"; $29.7 \%$ of bus drivers stated that "I know that individuals with DM should carry diabetes medical alert identification bracelet."

When examining the mean scores of bus drivers, who were 35 years old and younger, had an education level of high school and higher, had less than 1 year of work experience, had any chronic disease, had a family member with DM and received DM-related training at a health institution, there was a statistically significant difference between the drivers' level of knowledge and awareness of diabetic emergencies and their introductory characteristics $(\mathrm{p}<0.05)$. There was no statistically significant difference between the income status and encountering a diabetic passenger and the drivers' level of knowledge and awareness of diabetic emergencies $(\mathrm{p}>0.05)$ (Table 3).

\section{Discussion}

$\mathrm{DM}$ is a metabolic disease that poses a significant threat to the lives of drivers and other road users. The threats posed by DM increase by the presence of passengers with insulintreated DM who are at risk of developing hypoglycemic attacks. Informed drivers are needed to avoid immediate health risks of low blood pressure during the journey and reduce the risks of DM complications later to ensure metabolic control $[22,25]$. In this study, there was a statistically significant difference between the drivers' average scores for the level of knowledge and awareness regarding diabetic emergencies and their age, education status, work experience, the presence of chronic disease, the presence of diabetic family members, the presence of a first aid certificate, DM-related training, the place of receiving this training variables.

The average score of bus drivers participating in our study for the level of knowledge and awareness of diabetic emergency was found to be $15.39 \pm 4.72$. This result showed that the level of knowledge among bus drivers was slightly higher than the moderate level. Raising public awareness of DM is considered as the first step to control the progression of the disease, ensure its early detection, and prevent complications. There is evidence that raising awareness of DM and its complications provided significant benefits including increased adaptation to treatment, that reduced DM complications [26]. Although there are no studies assessing the level of knowledge and awareness of diabetic emergencies among bus drivers; studies involving different occupational groups showed that they had moderate and good knowledge of DM [21, 27].

It is important for bus drivers to be informed about DM to be able to detect the symptoms experienced by individuals during their journey and act at an early stage [22]. In the present study, the level of knowledge and awareness regarding diabetic emergencies among bus drivers who received DM-related training at health institutions were higher. A study of the relevant literature revealed that the levels of knowledge about DM among those who participated in diabetes education programs were significantly higher [28-31]; the main sources of information regarding DM were primarily health institutions and then, the Internet, media, and people in their environments [21, 22, 32-34]. This is believed to be because education is one of the methods to raise the awareness of DM and the participants received the information from the right source.

The level of public awareness of DM varies from person to person depending on socioeconomic conditions, cultural beliefs, education level, and personal development. It is stated that an in-depth understanding of these variables is necessary to prevent DM, as well as to develop and design preventive strategies to delay the development of its complications. According to our study, drivers younger than 35 years old, who had a high level of education and less than 1 year of work experience, had higher levels of knowledge and awareness of DM. Another study similar to the present study has found 
Table 1. Distribution of bus drivers according to personal characteristics ( $\mathrm{n}=1292)$.

\begin{tabular}{|c|c|c|}
\hline & \multicolumn{2}{|c|}{$\overline{\mathbf{X}} \pm$ SD (Min-Max) } \\
\hline Age & \multicolumn{2}{|c|}{$38.29 \pm 9.44(17-70)$} \\
\hline Weekly working hours & \multicolumn{2}{|c|}{$11.38 \pm 4.67(2-32)$} \\
\hline Work experience (years) & \multicolumn{2}{|c|}{$12.50 \pm 8.92(1-45)$} \\
\hline & $\mathrm{n}$ & $(\%)$ \\
\hline \multicolumn{3}{|l|}{ Gender } \\
\hline Male & 1292 & 100.0 \\
\hline \multicolumn{3}{|l|}{ Education status } \\
\hline Primary school & 146 & 11.3 \\
\hline Secondary school & 341 & 26.4 \\
\hline High school and above & 805 & 62.3 \\
\hline \multicolumn{3}{|l|}{ Marital status } \\
\hline Married & 1108 & 85.8 \\
\hline Single & 184 & 14.2 \\
\hline \multicolumn{3}{|l|}{ Income status } \\
\hline High & 244 & 18.9 \\
\hline Middle & 774 & 59.9 \\
\hline Low & 274 & 21.2 \\
\hline \multicolumn{3}{|l|}{ Presence of chronic disease } \\
\hline Yes & 134 & 10.4 \\
\hline No & 1158 & 89.6 \\
\hline \multicolumn{3}{|l|}{ Chronic diseases } \\
\hline Cardiovascular diseases & 30 & 22.4 \\
\hline Respiratory diseases & 26 & 19.4 \\
\hline Musculoskeletal diseases & 22 & 16.4 \\
\hline Endocrine diseases & 23 & 17.2 \\
\hline Digestive diseases & 20 & 14.9 \\
\hline Urinary system diseases & 13 & 9.7 \\
\hline \multicolumn{3}{|l|}{ Presence of family members with DM } \\
\hline Yes & 192 & 14.9 \\
\hline No & 1100 & 85.1 \\
\hline \multicolumn{3}{|l|}{ Degree of closeness with the family member with DM } \\
\hline $1^{\text {st }}$-degree relatives (son, daughter, spouse, son-in-law, daughter-in-law) & 118 & 61.5 \\
\hline $2^{\text {nd }}-$ degree relatives (mother, father, grandchild, sibling) & 54 & 28.1 \\
\hline $3^{\text {rd }}$-degree relative (uncle, aunt) & 20 & 10.4 \\
\hline \multicolumn{3}{|l|}{ First aid certificate presence } \\
\hline Yes & 306 & 23.7 \\
\hline No & 986 & 76.3 \\
\hline \multicolumn{3}{|c|}{ Status of information about which numbers to call in case of emergency } \\
\hline Yes & 1229 & 95.1 \\
\hline No & 63 & 4.9 \\
\hline \multicolumn{3}{|l|}{ Status of receiving DM-related training } \\
\hline Yes & 148 & 11.5 \\
\hline No & 1144 & 88.5 \\
\hline \multicolumn{3}{|l|}{ Place of receiving DM-related training } \\
\hline Healthcare institution & 90 & 61.2 \\
\hline Public education center & 27 & 18.4 \\
\hline Institution where I work & 15 & 10.9 \\
\hline Over the Internet & 14 & 9.5 \\
\hline \multicolumn{3}{|l|}{ Status of willingness to receive DM-related training } \\
\hline Yes & 901 & 69.7 \\
\hline No & 391 & 30.3 \\
\hline \multicolumn{3}{|l|}{ Status of having encountered a passenger with DM before } \\
\hline Yes & 1135 & 87.8 \\
\hline No & 157 & 12.2 \\
\hline
\end{tabular}

Notes: $\overline{\mathrm{X}}$ : mean; SD: standard deviation; Min: minimum; Max: maximum. 
Table 2. Distribution of bus drivers' responses to the 24-item Diabetic Emergency Information and Awareness Survey $(n=1292)$.

\begin{tabular}{|c|c|c|}
\hline Questions & $\begin{array}{c}\text { Yes } \\
\text { n }-\%\end{array}$ & $\begin{array}{l}\text { No } \\
\text { n- } \%\end{array}$ \\
\hline I know what DM is. & $1211-93.7$ & $81-6.3$ \\
\hline I know common symptoms of DM. & $1041-80.6$ & 251-19.4 \\
\hline I know what insulin is. & $1065-82.4$ & $227-17.6$ \\
\hline I know how much fasting blood sugar should be and the limit. & $695-53.8$ & $597-46.2$ \\
\hline I know how much satiety blood sugar should be and the limit. & $682-52.8$ & $610-47.2$ \\
\hline I know what type $1 \mathrm{DM}$ is. & $423-32.7$ & $869-67.3$ \\
\hline I know what type $2 \mathrm{DM}$ is. & $424-32.8$ & $868-67.2$ \\
\hline I have an idea of what gestational diabetes is. & $192-14.9$ & $1100-85.1$ \\
\hline I know that people with DM should carry a diabetes medical alert identification bracelet. & $384-29.7$ & $908-70.3$ \\
\hline I can get the passenger off the bus and lie them down on a flat, hard floor on their backs. & $1212-93.8$ & $80-6.2$ \\
\hline If there is a crowd around the passenger, I can disperse it and calm down the passenger. & $1209-93.6$ & $83-6.4$ \\
\hline I can assess the passenger's state of consciousness. & $1134-87.8$ & $158-12.2$ \\
\hline If the passenger is not conscious, I will not give any oral medications. & $1164-90.1$ & $128-9.9$ \\
\hline If the passenger has relatives, I will try to get information from them. & $1181-91.4$ & $111-8.6$ \\
\hline If the passenger has a blood glucose meter in their bag, I can measure their blood sugar. & $1181-91.4$ & $111-8.6$ \\
\hline $\begin{array}{l}\text { I can remain conscious and calm when interacting with passenger having high blood sugar or } \\
\text { low blood sugar. }\end{array}$ & $587-45.4$ & $705-54.6$ \\
\hline $\begin{array}{l}\text { I would not take any action if I thought I would harm the passenger with high blood sugar or } \\
\text { low blood sugar. }\end{array}$ & $1093-84.6$ & $199-15.4$ \\
\hline $\begin{array}{l}\text { I know that symptoms such as rapid and deep breathing, acetone breath, abdominal pain, nausea, } \\
\text { and vomiting are symptoms of high blood sugar; I can notice a passenger with } \\
\text { high blood sugar. }\end{array}$ & $1112-86.1$ & $180-13.9$ \\
\hline $\begin{array}{l}\text { I will check if the passenger with high blood sugar has a diabetes medical alert identification } \\
\text { bracelet; I can apply insulin if the patient has it in their bag. }\end{array}$ & $835-64.6$ & $457-35.4$ \\
\hline If the passenger with high blood sugar does not vomit, I will give them plenty of fluids. & $764-59.1$ & $528-40.9$ \\
\hline $\begin{array}{l}\text { I know that symptoms such as pale skin, sweating, headache, tingling on the lips and tongue, } \\
\text { weakness and hunger are symptoms of low blood sugar; I can notice a passenger with low } \\
\text { blood sugar. }\end{array}$ & $558-43.2$ & $734-56.8$ \\
\hline $\begin{array}{l}\text { I will check if the patient with low blood sugar has a diabetes medical alert identification } \\
\text { bracelet, and if the passenger is conscious; I can mix } 2 \text { sugar cubes in the water and give it } \\
\text { to the passenger. }\end{array}$ & $984-76.2$ & $308-23.8$ \\
\hline $\begin{array}{l}\text { If the passenger with low blood sugar is unconscious and has a glucagon injector in the bag, } \\
\text { I can apply it. }\end{array}$ & $317-24.5$ & $975-75.5$ \\
\hline $\begin{array}{l}\text { If the symptoms do not go away after the intervention for the passenger with low blood sugar, } \\
\text { I will call } 112 \text {. }\end{array}$ & $1185-91.7$ & $107-8.3$ \\
\hline Total ( $\overline{\mathbf{X}} \pm$ SD: Min - Max $)$ & \multicolumn{2}{|c|}{$15.39 \pm 4.72(0-24)$} \\
\hline
\end{tabular}

Notes: $\overline{\mathrm{X}}$ : mean; SD: standard deviation; Min: minimum; Max: maximum.

that participants younger than 39 years old had higher level of knowledge and awareness of diabetic emergencies than other age groups [20]. Additionally, many studies have found that people with high education levels had statistically better levels of knowledge and awareness of DM [26, 27, 29, 35, 36]. The reason for this situation is believed to be that young drivers who are new with the profession are more open to learning as their education level improves and want to be more aware of emergencies that may arise while traveling.

According to the present study, bus drivers with chronic disease having a DM family member had higher level of knowledge and awareness of diabetic emergencies. A study conducted by Kutbi et al. (2018) has found that individuals with chronic diseases such as hypertension had higher knowledge levels about DM [37]. According to the literature, individuals with a first-degree diabetic relative had higher knowledge levels about DM and were more aware of the measures to be taken $[20,23,36]$. The cause of this is believed to be counseling that individual who goes for a checkup with their family receives at each doctor's visit.

According to the findings of this study, $23.7 \%$ of bus drivers had first aid certificates, and those with first aid certifi- 
Table 3. Average scores of bus drivers on the level of knowledge and awareness of diabetic emergencies according to their personal characteristics $(n=1292)$.

\begin{tabular}{|c|c|c|}
\hline Personal characteristics & $\overline{\mathbf{X}} \pm \mathbf{S D}$ & \\
\hline \multicolumn{3}{|l|}{ Age } \\
\hline Younger than 35 & $15.96 \pm 4.18$ & \multirow{3}{*}{$\begin{array}{c}\text { KW }=10.149 \\
p=0.006\end{array}$} \\
\hline $35-54$ years & $15.08 \pm 4.83$ & \\
\hline Older than 55 years & $14.30 \pm 6.28$ & \\
\hline \multicolumn{3}{|l|}{ Education status } \\
\hline Primary school & $14.62 \pm 5.43$ & \multirow{3}{*}{$\begin{array}{c}\text { KW }=6.104 \\
p=0.047\end{array}$} \\
\hline Secondary school & $15.04 \pm 5.15$ & \\
\hline High school and above & $15.68 \pm 4.35$ & \\
\hline \multicolumn{3}{|l|}{ Income status } \\
\hline High & $15.57 \pm 4.85$ & \multirow{3}{*}{$\begin{array}{c}\mathrm{KW}=1.628 \\
\mathrm{p}=0.443\end{array}$} \\
\hline Middle & $15.23 \pm 4.71$ & \\
\hline Low & $15.68 \pm 4.60$ & \\
\hline \multicolumn{3}{|l|}{ Years of work experience } \\
\hline Less than 1 year & $16.94 \pm 4.13$ & \multirow{4}{*}{$\begin{array}{c}K W=15.141 \\
p=0.002\end{array}$} \\
\hline $1-5$ years & $15.67 \pm 4.23$ & \\
\hline $6-10$ years & $15.88 \pm 4.28$ & \\
\hline More than 10 years & $14.83 \pm 5.13$ & \\
\hline \multicolumn{3}{|l|}{ Presence of chronic disease } \\
\hline Yes & $16.47 \pm 6.13$ & $Z=\mathbf{~ 3 . 1 5 4}$ \\
\hline No & $15.27 \pm 4.51$ & $\mathbf{p}=\mathbf{0 . 0 0 2}$ \\
\hline \multicolumn{3}{|c|}{ Presence of family members with DM } \\
\hline Yes & $18.50 \pm 4.85$ & $Z=-9.736$ \\
\hline No & $14.85 \pm 4.48$ & $\mathbf{p}=\mathbf{0 . 0 0 0}$ \\
\hline \multicolumn{3}{|l|}{ First aid certificate } \\
\hline Yes & $17.66 \pm 4.05$ & $Z=\mathbf{- 9 . 5 3 9}$ \\
\hline No & $14.69 \pm 4.69$ & $\mathbf{p}=\mathbf{0 . 0 0 0}$ \\
\hline \multicolumn{3}{|c|}{ Status of receiving DM-related training } \\
\hline Yes & $20.19 \pm 4.38$ & $Z=-12.644$ \\
\hline No & $14.77 \pm 4.39$ & $\mathbf{p}=\mathbf{0 . 0 0 0}$ \\
\hline \multicolumn{3}{|c|}{ Place of receiving DM-related training } \\
\hline Healthcare institution & $21.18 \pm 3.88$ & \multirow{4}{*}{$\begin{array}{c}\mathrm{KW}=\mathbf{1 7 . 3 4 5} \\
\mathbf{p}=\mathbf{0 . 0 0 1}\end{array}$} \\
\hline Public education center & $17.55 \pm 5.08$ & \\
\hline Institution where I work & $18.81 \pm 4.59$ & \\
\hline Over the Internet & $20.50 \pm 3.73$ & \\
\hline \multicolumn{3}{|c|}{ Status of having encountered a passenger with DM before } \\
\hline Yes & $15.29 \pm 4.44$ & $\mathrm{Z}=-1.811$ \\
\hline No & $16.13 \pm 6.32$ & $\mathrm{p}=0.70$ \\
\hline
\end{tabular}

Notes: $\overline{\mathrm{X}}$ : mean; SD: standard deviation; Z: Mann-Whitney U test; KW: Kruskal Wallis test.

cates had higher levels of knowledge and awareness regarding diabetic emergencies. First aid is a practice that all individuals in a society, whether they have received health education or not, should do under all conditions [38]. A study conducted in India has found that $96.4 \%$ of commercial drivers knew what first aid was, but only $1.2 \%$ were trained [39]. According to studies involving different occupational groups, the first aid training increased the level of knowledge among individuals [40-42]. In the present study, it is assumed that the awareness levels of those holding a first aid certificate was high due to the information on low blood sugar in first aid.

\section{Conclusions \& Recommendations}

In this study, bus drivers had slightly higher levels of knowledge and awareness of diabetic emergencies than moderate. There was a statistically significant difference between drivers' age, education status, work experience, the presence of chronic disease, the presence of a family member with DM, the presence of a first aid certificate, the place of receiving DM-related education and the level of knowledge and awareness of diabetic emergencies. In this regard, bus drivers are recommended to be trained on diabetic emergencies and raising awareness of DM to ensure a proper intervention in case of emergencies in individuals with DM during travels. In particular, the training provided should consider the sociodemographic characteristics that prevent DM knowledge and awareness. At the end of each training session, role-play exercises involving diabetic individuals and bus drivers should be performed. According to the findings of the present study, the sources of information about DM are healthcare professionals, as well as communication media such as television and radio. These communication tools should be used more for training. However, these sources of information need to be audited for accuracy. Additionally, buses are recommended to have mini coolers where people with DM can store their insulin during long trips, as well as to take some steps to ensure that existing facilities are used effectively by people with DM.

\section{Ethical Statement \& Informed Consent}

Before data collection, Ethics Committee approval was gained from the Ethics Committee of Non-Interventional Clinical Studies of the Burdur Mehmet Akif Ersoy University (Decision Number: GO 2018/14). Written permission was obtained from the driver's chamber or registered cooperatives in the provinces where the study was conducted. Informed written consent was obtained from the participating bus drivers. The study protocol was conducted according to the Declaration of Helsinki.

\section{Acknowledgements}

The authors would like to thank all the participants.

\section{Conflict of Interest}

The authors declare that no conflicts exist.

\section{Financial Disclosure}

The authors declared no financial support. 


\section{References}

[1] Turkish Diabetes Foundation. 2010-2020 National Diabetes Strategy Outcome Document. İstanbul: Turkish Diabetes Foundation; 2010. Available from: https://www.turkdiab.org/admin/PICS/webfiles/D_2020_ Ulusal_Diyabet_Stratejisi_Sonuc_dokumani_20010_ 2020.pdf

[2] Turkish Ministry of Health, Public Health Institution of Turkey. Turkey Diabetes Program (2015-2020). Available from: https:/extranet.who.int/ncdccs/Data/TUR_D1_ T\%C3\%BCrkiye \%20Diyabet $\% 20$ Program $\%$ C4\%B1\% 202015-2020.pdf

[3] International Diabetes Federation (IDF). IDF Diabetes Atlas, 9th edition. Brussels, Belgium: International Diabetes Federation; 2019. Available from: https://diabetesatlas.org/en/

[4] Satman I, Imamoglu Ş, Yılmaz C, Ayvaz G, Çömlekçi A. Diabetes in Turkey and in the World. Turkish Journal of Endocrinology and Mertabolism. 2012;16(1):1-50. Available from: http://www.turkjem.org/uploads/pdf/161-1_Diyabet_Raporu.pdf

[5] Satman İ. Epidemiology of diabetes mellitus. In: İmamoğlu Ş, editor. Diagnosis, Treatment and Follow-up with a Multidisciplinary Approach. İstanbul: Deomed; 2009;11-35.

[6] Gagneux-Brunon A, Andrillat C, Fouilloux P, Daoud F, Defontaine C, Charles R, et al. Pre-travel advice seeking from GPs by travellers with chronic illness seen at a travel clinic. J Travel Med. 2016;23(3):1-5. Available from: https://doi.org/10.1093/jtm/taw013

[7] Flatherty GT, Leong SW, Finn Y, Sulaiman LH, Noone C. Travellers with type 1 diabetes: questionnaire development and descriptive analysis of knowledge and practices. J Travel Med. 2020;27(6):1-28. Available from: https://doi.org/10.1093/jtm/taaa110

[8] Lin IW, Chang $\mathrm{HH}$, Lee $\mathrm{YH}, \mathrm{Wu} \mathrm{YC,} \mathrm{Lu} \mathrm{CW,}$ Huang KC. Blood sugar control among type 2 diabetic patients who travel abroad: A cross sectional study. Medicine. 2019;98(13):1-4. Available from: https://doi.org/10.1097/md.0000000000014946

[9] Mullin R, Kruger D, Young CF, Shubrook JH. Navigating travel with diabetes. Cleve Clin J Med. 2018;85(7):537-542. Available from: https://doi.org/10.3949/ccjm.85a.17105

[10] Morteza I, Mahboobeh Sadat H, Hossein P. Travel guidance for people with diabetes. International Journal of Travel Medicine and Global Health. 2015;3(4):149-154. Available from: https://doi.org/10.20286/ijtmgh0304128
[11] Pavela J, Suresh R, Blue RS, Mathers CH, Belalcazar LM. Management of diabetes during air travel: A systematic literature review of current recommendations and their supporting evidence. Endocr Pract. 2018;24(2):205-219. Available from: https://doi.org/10.4158/ep171954.ra

[12] Alduraibi R, Almigbal T, Alrasheed A, Batais MA. Knowledge, attitudes, and practices of primary health care physicians regarding the pre-travel counselling of patients with type 2 diabetes in Riyadh, Saudi Arabia. BMC Fam Pract. 2020;21(1):1-9. Available from: https://doi.org/10.1186/s12875-020-01273-z

[13] Priya G, Kalra S, Dutta D, Grewal E, Maisnam I, Aggarwal S. Up in the air with diabetes: A systematic review of literature and a pragmatic approach to diabetes management during long-distance travel. J Diabetes Metab Disord. 2020;7(31):1-10. Available from: https://doi.org/10.24966/DMD-201X/100031

[14] Charlton AR, Charlton JR. World travel with type 1 diabetes using continuous subcutaneous insulin infusion. Br J Diabetes. 2019;19(2):141-146. Available from: https://doi.org/10.15277/bjd.2019.224

[15] Beltran G. Diabetic emergencies: New strategies for an old disease. Emerg Med Pract. 2014;16(6):1-20. Available from: https://pubmed.ncbi.nlm.nih.gov/25299033/

[16] Saruhan Ç, Saruhan R, Yıldırım C, Ovayolu N. Determination of first aid knowledge levels of the teachers working in the government primary schools in Gaziantep city. Batman University Journal of Life Sciences. 2018;8(1/2):36-46. Available from: https://dergipark.org.tr/tr/download/article-file/492063

[17] Kılıç S. Sample size, power concepts and sample size calculation. Journal of Mood Disorders. 2012;2(3):140-142. Available from: https://doi.org/10.5455/jmood.20120921043306

[18] Tarı Selçuk K, Ünal B. Determinants of prevelance and awareness of diabetes in a population aged $45-74$ in Bigadic. Turk J Public Health. 2013;11(3):160-173. Available from: https://doi.org/10.20518/tjph.173081

[19] Marcinkiewicz A, Szosland D. Selected risk factors of diabetes mellitus among road transport drivers. Int J Occup Med Environ Health. 2010;23(2):175-180. Available from: https://doi.org/10.2478/v10001-010-0018-3

[20] Al-Maskari F, El-Sadig M, Al-Kaabi JM, Afandi B, Nagelkerke N, Yeatts KB. Knowledge, attitude and practices of diabetic patients in the United Arab Emirates. PloSOne. 2013;8(1):e52857. Available from: https://doi.org/10.1371/journal.pone.0052857 
[21] Almalki ZA, Almarzoqi GS, Assery MS, Alzahrani TA, Alharthi NH, Alosaimi SM, et al. Awareness and knowledge of diabetes mellitus among school teaching staff in Taif City. Int J Med Surg. 2018;(5):1-6. Available from: https://doi.org/10.15342/ijms.v5ir.241

[22] Amissah I, Barnes A, Craymah P, Eliason S. Knowledge of diabetes mellitus and management practices among senior high school teachers in Ghana. International Journal of Science and Research. 2017;6(1):1090-1095. Available from: https://doi.org/10.4274/jcrpe.756

[23] Asmamaw A, Asres G, Negese D, Fekadu A, Assefa G. Knowledge and attitude about diabetes mellitus and its associated factors among people in Debre Tabor town, Northwest Ethiopia: cross sectional study. Science Journal of Public Health. 2015;3(2):199-209. Available from: https://doi.org/10.11648/j.sjph.20150302.17

[24] Gillani AH, Islam A, Mohammad F, Hayat K, Atif $\mathrm{N}$, Yang $\mathrm{C}$, et al. Knowledge, attitudes and practices regarding diabetes in the general population: a cross-sectional study from Pakistan. Int J Environ Res Public Health. 2018;15(1906):1-13. Available from: https://doi.org/10.3390/ijerph15091906

[25] Adedokun AO, Ter Goon D, Owolabi EO, Adeniyi OV, Ajayi AI. Prevalence, awareness, and determinants of type 2 diabetes mellitus among commercial taxi drivers in buffalo city metropolitan municipality South Africa: A cross-sectional survey. Medicine. 2019;98(9):e14652. Available from: https://doi.org/10.1097/MD.0000000000014652

[26] Deepa M, Bhansali A, Anjana RM, Pradeepa R, Joshi SR, Joshi PP. Knowledge and awareness of diabetes in urban and rural India: the Indian Council of Medical Research India diabetes study (phase I): Indian Council of Medical Research India Diabetes 4. Indian J Endocrinol Metab. 2014;18(3):379-385. Available from: https://doi.org/10.4103/2230-8210.131191

[27] Herath HMM, Weerasinghe NP, Dias H, Weerarathna TP. Knowledge, attitude and practice related to diabetes mellitus among the general public in Galle district in Southern Sri Lanka: a pilot study. BMC Public Health. 2017;17:535. Available from: https://doi.org/10.1186/s12889-017-4459-5

[28] Alotaibi A, Gholizadeh L, Al-Ganmi A, Perry L. Examining perceived and actual diabetes knowledge among nurses working in a tertiary hospital. Appl Nurs Res. 2017;35:24-29. Available from: https://doi.org/10.1016/j.apnr.2017.02.014

[29] Alemayehu AM, Dagne H, Dagnew B. Knowledge and associated factors towards diabetes mellitus among adult non-diabetic community members of Gondar city, Ethiopia 2019. PLoS One. 2020;15(3):e0230880. Available from: https://doi.org/10.1371/journal.pone.0230880

[30] Kassahun CW, Mekonen AG. Knowledge, attitude, practices and their associated factors towards diabetes mellitus among non-diabetes community members of Bale Zone administrative towns, South East Ethiopia. A crosssectional study. PloS One. 2017;12:e0170040. Available from: https://doi.org/10.1371/journal.pone.0170040

[31] Hartayu TS, Mi MI, Suryawati Sri. Improving of type 2 diabetic patients' knowledge, attitude and practice towards diabetes self-care by implementing community-based interactive approach-diabetes mellitus strategy. BMC Res Notes. 2012;5:315. Available from: https://doi.org/10.1186/1756-0500-5-315

[32] Nansseu JR, Petnga SJN, Atangana CP, Ossa AS, Sangong SNN, Ebendeng $P$, et al. The general public's knowledge of diabetes mellitus: A cross-sectional study in Cameroon. Prim Care Diabetes. 2019;13(2):97-105. Available from: https://doi.org/10.1016/j.pcd.2018.10.003

[33] Mbuya FE, Fredrick F, Kundi B. Knowledge of diabetes and hypertension among members of teaching staff of higher learning institutions in Dar es Salaam, Tanzania. Tanzan J Health Res. 2014;16(2):98-103. Available from: https://doi.org/10.4314/thrb.v16i2.5

[34] Chopra N, Narang B, Iqbal J. Diabetes management in schools: Teachers' knowledge, attitude and care practices. Internat J Appl Home Sci. 2017;4(5\&6):259-264. Available from: http://scientificresearchjournal.com/wpcontent/uploads/2017/05/Home-Science-Vol-4_A-259264-Full-Paper.pdf

[35] Salem A, Majed A, Mustafa MAM, Abdulsalam A, Asdaq SMB, Mohammed A. Knowledge, attitude, and practice regarding diabetes mellitus among general public and diabetic patients in Riyadh, Saudi Arabia. Asian J Pharm. 2018;12(01):1-9. Available from: https://doi.org/10.22377/ajp.v12i01.2071

[36] Alsous M, Jalil MA, Odeh M, Al Kurdi R, Alnan M. Public knowledge, attitudes and practices toward diabetes mellitus: A cross-sectional study from Jordan. PloS One. 2019;14(3):1-12. Available from: https://doi.org/10.1371/journal.pone.0214479

[37] Kutbi HA, Mosli HH, Alhasan AH, Mosli RH. Diabetes knowledge and its association with the weight status among residents of Jeddah City, Saudi Arabia. Nutr Diabetes. 2018;8(1):48-56. Available from: https://doi.org/10.1038/s41387-018-0055-8 
[38] İnan HF, Kurt Z, Kubilay İ. Temel İlkyardım Uygulamaları Eğitim Kitabı. Ankara: T.C. Sağlık Bakanlığı Temel Sağlık Hizmetleri Genel Müdürlüğü, İlkyardım ve Acil Sağlık Hizmetleri Daire Başkanlığ1; 2011. Available from: https://istanbulism.saglik.gov.tr/Eklenti/63991/0/temelilkyardim-uygulamalari-beceri-rehberipdf.pdf

[39] Awasthi S, Pamei G, Solanki HK, Kaur A, Bhatt M. Knowledge, attitude, and practice of first aid among the commercial drivers in the Kumaon region of India. J Family Med Prim Care. 2019;8:1994-1998. Available from: https://doi.org/10.4103/jfmpc.jfmpc_295_19

[40] Doğar A, Tozoğlu E, Şam CT. Investigation of the first aid principles and awareness levels of officers who work in Erzurum provincial gendarmerie command. International Social Mentality and Researcher Thinkers Journal. 2021;7(42):371-376. Available from: https://doi.org/10.31576/smryj.822
[41] Andsoy I, Şahin AO, Ural S. The efficiency evaluation to first aid training given to security personnel in a state university. Çă̆daş Med J. 2014;4(2):84-90. Available from: https://dergipark.org.tr/tr/pub/gopctd/issue/7311/95660

[42] Şahin M, Aslan R. Investigation of the Effectiveness of First Aid Course in a Public Education Center. Gümüşhane University Journal of Health Sciences. 2019;8(4):390-396. Available from: https://dergipark.org.tr/tr/download/article-file/913314

Received: 2021-07-23

Revised: 2021-08-05

Accepted: 2021-08-10 